\title{
TDOS/PDOS/OPDOS, reduced density gradient (RDG) and molecular docking studies of [3-(3-bromophenyl)-cis-4,5-dihydroisoxazole-4,5- diyl]bis(methylene) diacetate
}

\author{
Yesim S. KARA ${ }^{1 *}$, Aslı ESME ${ }^{2}$, Seda G. SAGDINC ${ }^{3}$ \\ ${ }^{I}$ Department of Chemistry, Science and Art Faculty, Kocaeli University, 41380, Umuttepe, Kocaeli, \\ Turkey \\ ${ }^{2}$ Department of Elementary Science Education, Kocaeli University, 41380, Umuttepe, Kocaeli, Turkey \\ ${ }^{3}$ Department of Physics, Science and Art Faculty, Kocaeli University, 41380, Umuttepe, Kocaeli, Turkey
}

Geliş Tarihi (Received Date): 28.01.2021 Kabul Tarihi (Accepted Date): 02.08.2021

\begin{abstract}
Due to the wide range of biological activity, 4,5-dihydroisoxazole compounds form an important family of five-membered heterocycles containing an oxygen atom and a nitrogen atom in the adjacent position. Therefore, [3- (3-bromophenyl) -cis-4,5dihydroisoxazol-4,5-yl] bis (methylene) diacetate [BDBD] compound, which is a derivative of 4,5-dihydroisoxazole, was investigated in this study. The partial density of state (PDOS), the overlap population density of state (OPDOS) and total density of state (TDOS) of functional groups of the [BDBD] compound were theoretically evaluated using the DFT / B3LYP / 6-311G (d,p) method. Reduced density gradient $(R D G)$ was also given to study the weak interaction, strong attraction, and strong repulsion interactions of the studied molecule. The PASS (Prediction of Activity Spectra) analysis predicts the carcinogenic activities with probability to be active value of 0.273 for the studied molecule. The antibacterial and anti-inflammatory activities of the [BDBD] compound against various the HIV-1 protease (1HSG), GyrB ATPase (3U2D), and VEGFR-2 kinase enzyme (4AG8) proteins were studied using molecular docking. The binding energies of $1 H S G, 3 U 2 D$, and $4 A G 8$ target proteins with [BDBD] ligand were calculated to be $-6.11,-4.54$, and $-4.80 \mathrm{kcal} / \mathrm{mol}$, respectively. Results were interpreted by comparing with the literature.
\end{abstract}

Keywords: DFT, 4,5-dihydroisoxazole, molecular orbital density of states, reduced density gradient (RDG), molecular docking

\footnotetext{
*Yesim S. KARA, yesimkara@kocaeli.edu.tr, http://orcid.org/0000-0003-3498-0513

Aslı EŞME, asli.esme@kocaeli.edu.tr, http://orcid.org/0000-0003-2573-306X

Seda G. SAGDINC, seda.sagdinc@kocaeli.edu.tr, http://orcid.org/0000-0003-4765-6990
} 


\section{[3-(3-bromofenil)-cis-4,5-dihidroisoksazol-4,5- il]bis(metilen)diasetat molekülünün TDOS/PDOS/OPDOS, azaltılmış yoğunluk gradyanı (RDG) ve moleküler yerleştirme çalışmaları}

\section{$\ddot{\mathbf{O} z}$}

Geniş biyolojik aktivite yelpazesi nedeniyle, 4,5-dihidroisoksazol bileşikleri, bir oksijen atomu ve bir nitrojen atomunu bitişik pozisyonda ihtiva eden beş üyeli heterosikliklerin önemli bir ailesini oluşturur. Bu nedenle 4,5-dihidroizoksazol türevi olan [3- (3bromofenil) -cis-4,5-dihidroisoksazol-4,5-yl] bis (metilen) diasetat [BDBD] bileşiği bu çalışmada incelenmiştir. [BDBD] bileşiğinin fonksiyonel gruplarının kısmi durum yoğunluğu (PDOS), örtüşen nüfus yoğunluğu (OPDOS) ve toplam durum yoğunluğu (TDOS) DFT / B3LYP / 6-311G (d,p) yöntemi kullanılarak teorik olarak değerlendirildi. Azaltılmış yoğunluk gradyanı (RDG), molekülün zaylf etkileşimi, güçlü çekiciliği ve güçlü itme etkileşimlerini incelemek için verildi. PASS (Biyolojik Aktivite Spektrumunu Tahmin etme) analizi aktif olma olasılık verisi 0.273 ile incelenen molekül için kanserojen aktivitesini önerir. [BDBD] bileşiğinin seçilmiş bazı HIV-1 proteaz (1HSG), GyrB ATPase (3U2D) ve VEGFR-2 kinaz enzimi (4AG8) proteinlerine karşl antibakteriyel ve anti-inflamatuar aktiviteleri moleküler yerleştirme yöntemiyle araştırıldı. 1HSG, 3U2D, and 4AG8 hedef proteinleri ile [BDBD] ligandı bağlanma enerjileri sırasıyla -6.11, -4.54, and $-4.80 \mathrm{kcal} / \mathrm{mol}$ olarak hesaplandl. Sonuçlar literatürle karşılaştırılarak yorumlanmıştır.

Anahtar kelimeler: DFT, 4,5-dihidroisoksazol, moleküler orbital durum yoğunluğu, azaltılmış yoğunluk gradyanı (RDG), moleküler yerleştirme

\section{Introduction}

4,5-dihydroisoxazoles belong to an important class of heterocyclic compounds. Because they are used several useful synthetic synthesis of units such as to $\alpha, \beta$ unsaturated ketones, $\beta$-hydroxy ketones, $\beta$-ketols, $\gamma$-amino alcohols, $\alpha, \beta$-unsaturated oximes and $\beta$-hydroxynitriles [1-5]. The chemistry of 4,5-dihydroisoxazole has been an interesting field of study for decades because of their prominent potential as analgesic, anti-inflammatory, anticancer, antimicrobial, antiviral, anticonvulsant, antidepressant, and immunosuppressant [6-9]. Emir et al. [10] reported that they detected very high anti-inflammatory activity by carrageenan-induced rat paw edema method, a 4,5dihydroisoxazole derivative compound carrying the indole fragment they synthesized. A series of 4,5-dihydro derivative compounds by Gautam and Singh [11] tested in vitro for antibacterial activities against S. aureus, B. subtilis, E. coli and P. aeruginosa and compound 5-(3-chlorophenyl)-3-(thiophen-2-yl)-4,5-dihydroisoxazole was found to be quite high active against E. coli and P. aeruginosa due to increased lipid solubility the presence of chloride in the aromatic ring. Starting material is variable according to type of nitrile oxide. Starting material is variable according to type of nitrile oxide. Aromatic nitrile oxides are produced from the derivatives of hydroxamic acids, and aliphatic nitrile oxides from primary nitro compounds [12]. The synthesis of [3-(3bromophenyl)-cis-4,5-dihydroisoxazole-4,5-diyl]bis(methylene)diacetate (BDBD) was 
previously given in substituent effect study on experimental ${ }^{13} \mathrm{C}$ NMR chemical shifts of 4,5-dihydroisoxazole derivatives [13]. In our previous study, the crystal structure of the BDBD compound was investigated using single-crystal X-ray diffraction analysis [14]. In addition, Hirshfeld surface analysis, fingerprint graphics, optimized molecular structure analysis, frontier molecular orbital analysis, quantum chemical parameters, NMR chemical shifts and vibrational frequency analysis were studied by theoretically [14]. In this study, we report its molecular orbital density of states (TDOS/ PDOS/OPDOS), reduced density gradient (RDG) study, and molecular docking study using theoretical calculations.

\section{Experimental and calculations}

\subsection{Materials and physical measurements}

The structure of [3-(3-bromophenyl)-cis-4,5-dihydroisoxazole-4,5 diyl] bis (methylene) diacetate compound studied is given in the Scheme.

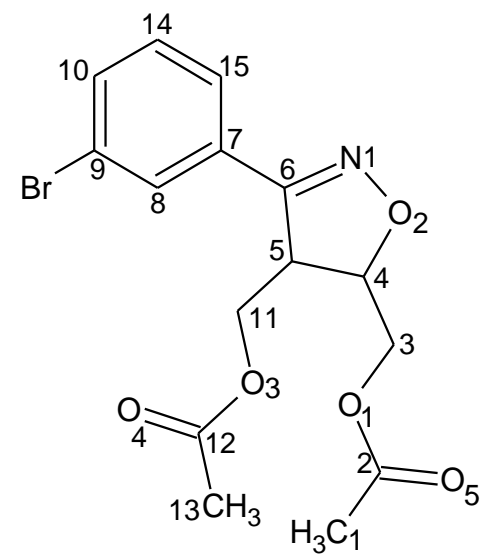

Scheme. [3-(3-bromophenyl)-cis-4,5-dihydroisoxazole-4,5 diyl] bis (methylene) diacetate.

\subsection{Calculation methods}

DFT calculations were carried out the Gaussian 09 Rev. A 11.4 package program [15] to visualize by the GaussView Rev. 5.0.9 software [16] program. X-ray structural parameters of BDBD was used as initial guess for geometry optimization [13]. The molecular structure of the studied compound in the ground state was optimized by the using the three-parameter hybrid functional of Becke based on the correlation functional of Lee, Yang, and Parr (B3LYP) level $[17,18]$ at the 6-311G(d,p) basis set. The Reduced Density Gradient (RDG) was obtained from Multiwfn 3.4.1 software, which is a multifunctional wavefunction analysis program and rendered by the VMD 1.9.1 program $[19,20]$. The total density of states (TDOS), the partial density of state (PDOS) and the overlap population density of state (OPDOS) of BDBD obtained using the same method was also evaluated with of Multiwfn 3.4.1 program [19]. 


\section{Result and discussion}

\subsection{Total, partial and overlap density of states}

The original density of states (DOS) graph does not provide any additional information except energy level distribution. The total density of states (TDOS) is the sum of density contributions from each fragment orbitals using the partial density of states (PDOS) calculation. To plot the TDOS graph (the black curve) using the Multiwfn 3.4.1 suite version [20], fragments f1-f5 of the BDBD compound are defined as five groups, which are assigned as isoxazole ring, phenyl ring, methyl $\left(-\mathrm{CH}_{3}\right)$ groups, methylene $\left(-\mathrm{CH}_{2}\right)$ groups, and hydrogens, respectively, and the results are represent in Fig. 1.

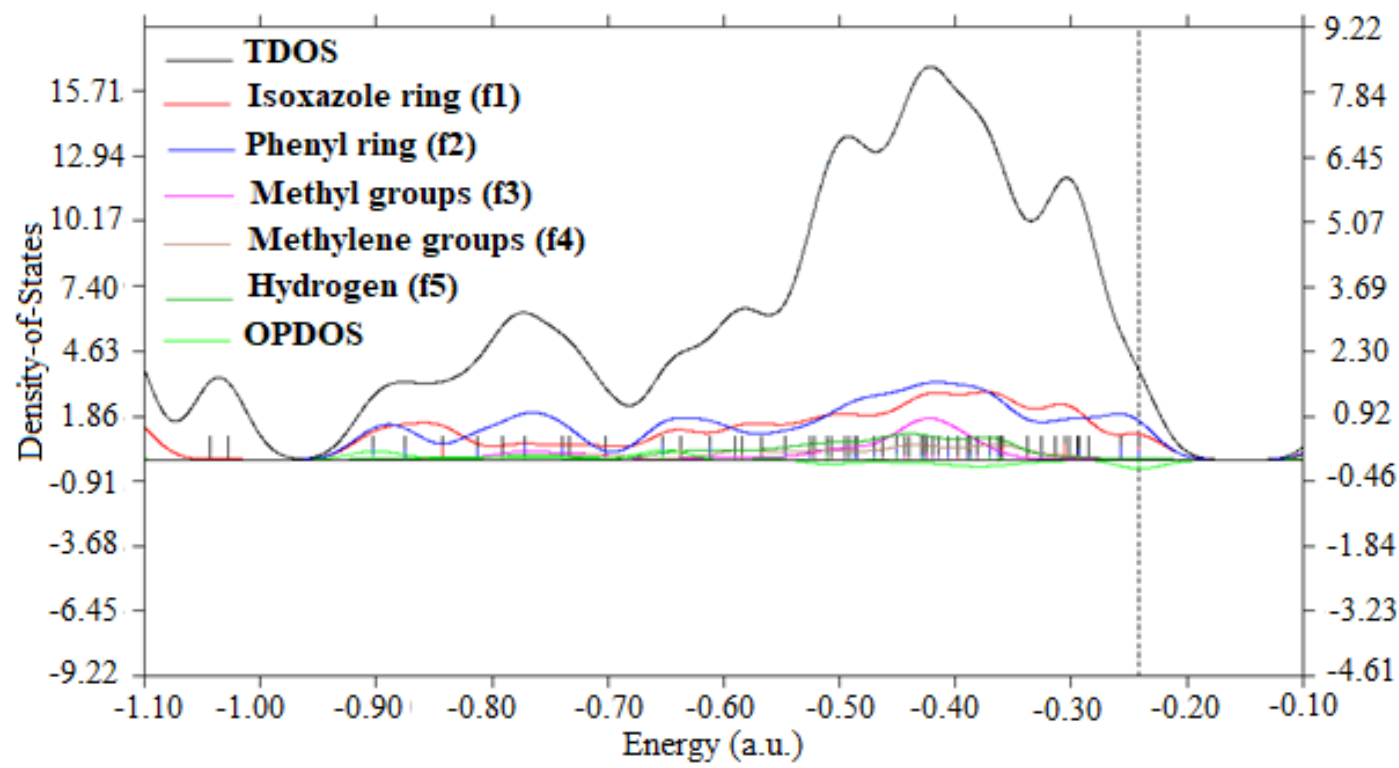

Fig. 1. Molecular orbital density of states (DOS) in BDBD with respect to f1-f5 functional groups.

The vertical dashed line shows the position of the HOMO level. The red, blue, magenta, brown, dark green curves and discrete lines represent PDOS of fragment 1, 2, 3,4 , and 5, respectively. The f1 (red curve) and f2 (blue curve) belong to isoxazole and phenyl rings have the contribution in the HOMO level between $-0.35--0.60$ a.u., and the other contribution is by the $\mathrm{f} 3$ methyl groups $(-0.40--0.50$ a.u.) denoted as the pink line in PDOS spectrum. The ranges of the Y-axis corresponding to overlap density of states (OPDOS) are set to -4.61, 9.22 (right side). The OPDOS values of BDBD are almost zero, which means that there is weak covalent character in the studied compound.

\subsection{Reduced density gradient ( $R D G)$}

Johnson and co-workers [21] studied Reduced density gradient (RDG), which describes the weak interactions come from the quantum-mechanical electron density and its first derivatives in real space. The electron density value in a reduced density gradient, which a fundamental dimensionless quantity called RDG provides information about interaction strength and is defined as: 


$$
R D G(r)=\frac{1}{2\left(3 \pi r^{2}\right)^{1 / 3}} \frac{|\nabla \rho(r)|}{\rho(r)^{4 / 3}}
$$

where the $\rho(r)$ is the electron density and $|\nabla \rho(r)|$ is the norm of the electron density vector. The sign of $\lambda$ is used to distinguish bonded $\left(\lambda_{2}<0\right)$ from non-bonded $\left(\lambda_{2}>0\right)$. To better define the nature of the intermolecular interaction of BDBD, the RDG analysis results plotted by the Multiwfn 3.4.1 package and VMD programs are shown in Fig. 2 $[20]$.
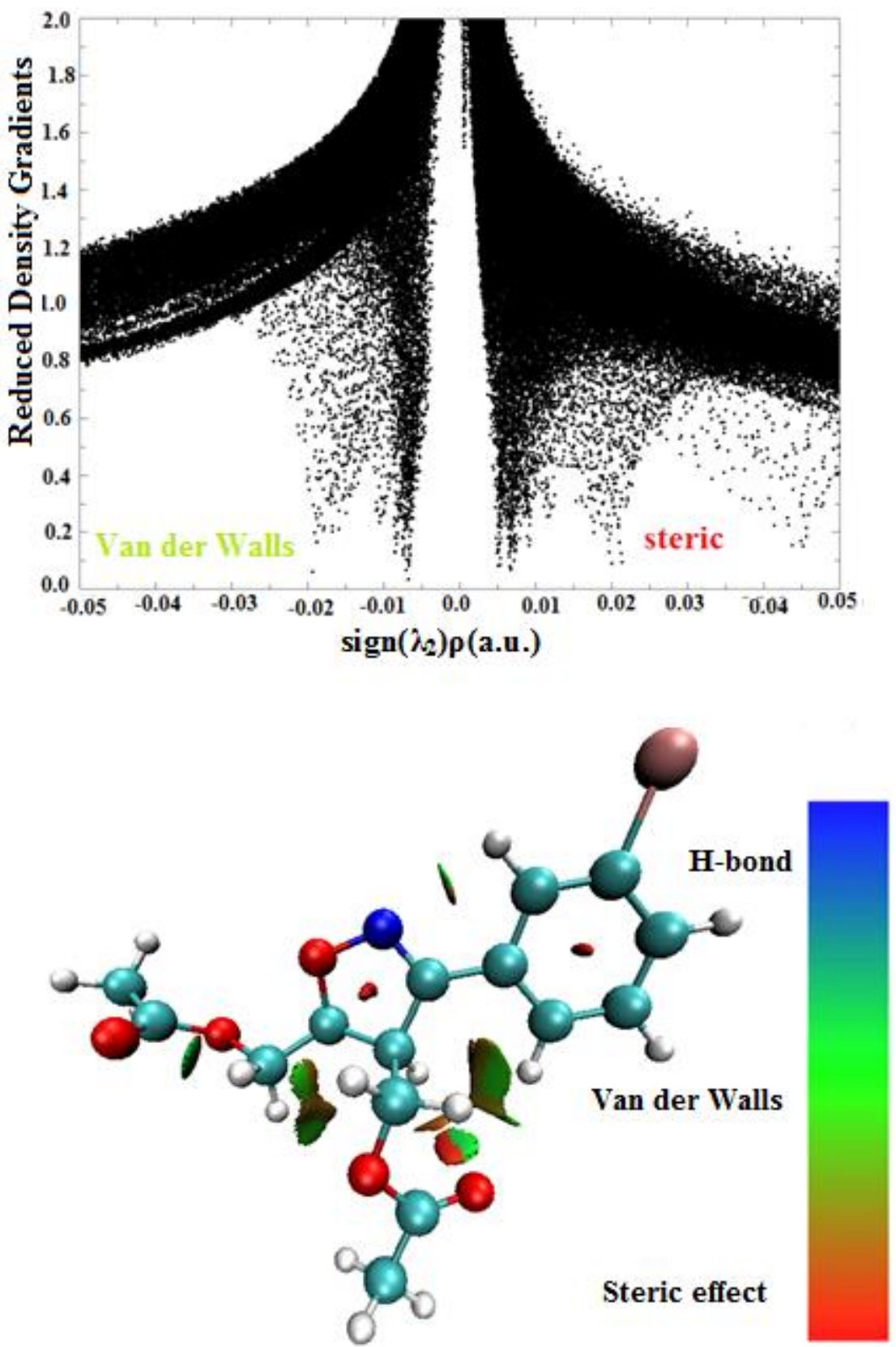

Fig. 2. The plot of reduced density gradient (RDG) scatter (up), the color filled isosurface of $\operatorname{BDBD}($ down). 
In the scatterplot [Fig. 2. (up)], many spikes are found in the region $-0.05-+0.05$ a.u. Combining with Fig. 2. (up), negative values of sign $\left(\lambda_{2}\right) \rho$ (left side of Fig. 2.) are indicative of attractive interactions with the other molecule, while positive values of sign $\left(\lambda_{2}\right) \rho$ (right side of Fig. 2.) indicate strong repulsion interactions (steric effect). As can be seen in Fig. 2., the isosurfaces of RDG for BDBD show that a strong Van der Waals interaction can be observed between the methylene groups and hydrogens indicated by green-brown isosurfaces. It can be seen that in the middle of the isoxazole, phenyl rings and around the $\mathrm{C}=\mathrm{O}$ bond there are red fusiform areas, which reflect strong steric effect.

\subsection{Molecular docking study}

$\mathrm{Pa}$ (states probability to be active) and $\mathrm{Pi}$ (probability to be inactive) values tell the probability of biological activity of BDBD. The studied molecule has $\mathrm{Pa}=0.273$ and $\mathrm{Pi}=0.114$ values using the PASS (Prediction of Activity Spectra) computational program which predicts the carcinogenic activities [22]. Isoxazole compounds are well known for wide biological activities as anti-inflammatory, antimicrobial, antifungal and antibacterial [23].

The molecular docking studies were performed using the AutoDock version 4.2 program with the AutoDockTools (ADT) version 1.5.6 to explorer the binding energy $(\mathrm{kcal} / \mathrm{mol})$, inhibition constant $(\mu \mathrm{M})$, intermolecular energy $(\mathrm{kcal} / \mathrm{mol})$, and bond distances $(\AA)$ for BDBD with targeted the HIV-1 protease (PDB ID: 1HSG), GyrB ATPase (PDB ID: 3U2D), and VEGFR-2 kinase enzyme (PDB ID: 4AG8) proteins which have the properties of anticancer, antimicrobial, and anti-inflammatory activities, respectively [24]. The graphical interface ADT was used to remove the all hetero atoms and water molecules in the targeted 1HSG, 3U2D, and 4AG8 proteins. Polar hydrogen bond and Kollman charges were added to the 1HSG, 3U2D, and 4AG8 proteins and then Lamarckian Genetic Algorithm (LGA) was used for molecular docking calculations in the AutoDock 4.2 program [25]. After molecular docking studies, Discovery Studio Visualizer software was used to visualize the docking results and search the interactions between ligand and receptor proteins [26].

Isoxazoline derivatives are an important class of five membered nitrogen-oxygen containing heterocyclic compounds that exhibited promising anticancer properties [27]. The optimized structure for BDBD from Gaussian 09 [9] was used to dock into the active sites of receptors 1HSG, 3U2D, and 4AG8 of the anticancer, antimicrobial, and anti-inflammatory proteins downloaded from the Research Collaboratory for Structural Bioinformatics (RCSB). The interactions of BDBD molecule with the 1HSG, 3U2D, and 4AG8 proteins are shown in Fig. 3. The molecular docking binding energies, inhibition constants, intermolecular energies, and bond distances $(\AA)$ for BDBD with targeted 1HSG, 3U2D, and 4AG8 proteins were listed in Table 1. The minimum binding energies of $1 \mathrm{HSG}, 3 \mathrm{U} 2 \mathrm{D}$, and $4 \mathrm{AG} 8$ are $-6.11,-4.54$, and $-4.80 \mathrm{kcal} / \mathrm{mol}$, the intermolecular energies were $-8.20,-6.63$, and $-6.89 \mathrm{kcal} / \mathrm{mol}$ with the interactions, respectively. The bonded residues and bond lengths were LYS-55, LYS-55, GLU-35, ARG-57 and 2.1, 3.6, 2.7, $2.0 \AA$ for 1HSG, LYS-155, GLN-159 and 1.8, $1.8 \AA$ for 3U2D, ARG-1124, GLY-1145 and 2.1, 3.3 $\AA$ for 4AG8, respectively. The docking results of BDBD revealed that the amino acids LYS-55, GLU-35, ARG-57 / LYS-155, GLN-159 / ARG-1124, GLY-1145 in the active sites of the target 1HSG / 3U2D / 4AG8 proteins bind with the title compound by $\mathrm{C}=\mathrm{O}$ bonds, $\mathrm{N} 1$ atom, $\mathrm{O} 2$ atom / $\mathrm{C} 2=\mathrm{O} 5$ bond, $\mathrm{C} 12=\mathrm{O} 4$ bond $/ \mathrm{C}=\mathrm{O}$ bond, $\mathrm{O} 2$ atom, respectively. It also showed that 
the presence of the isoxazole ring plays an important role in protein-ligand interaction [28]. No traces of antibacterial and anti-inflammatory impact were observed from the studied ligand These preliminary results support the exhibited anticancer activity of the BDBDmolecule. 


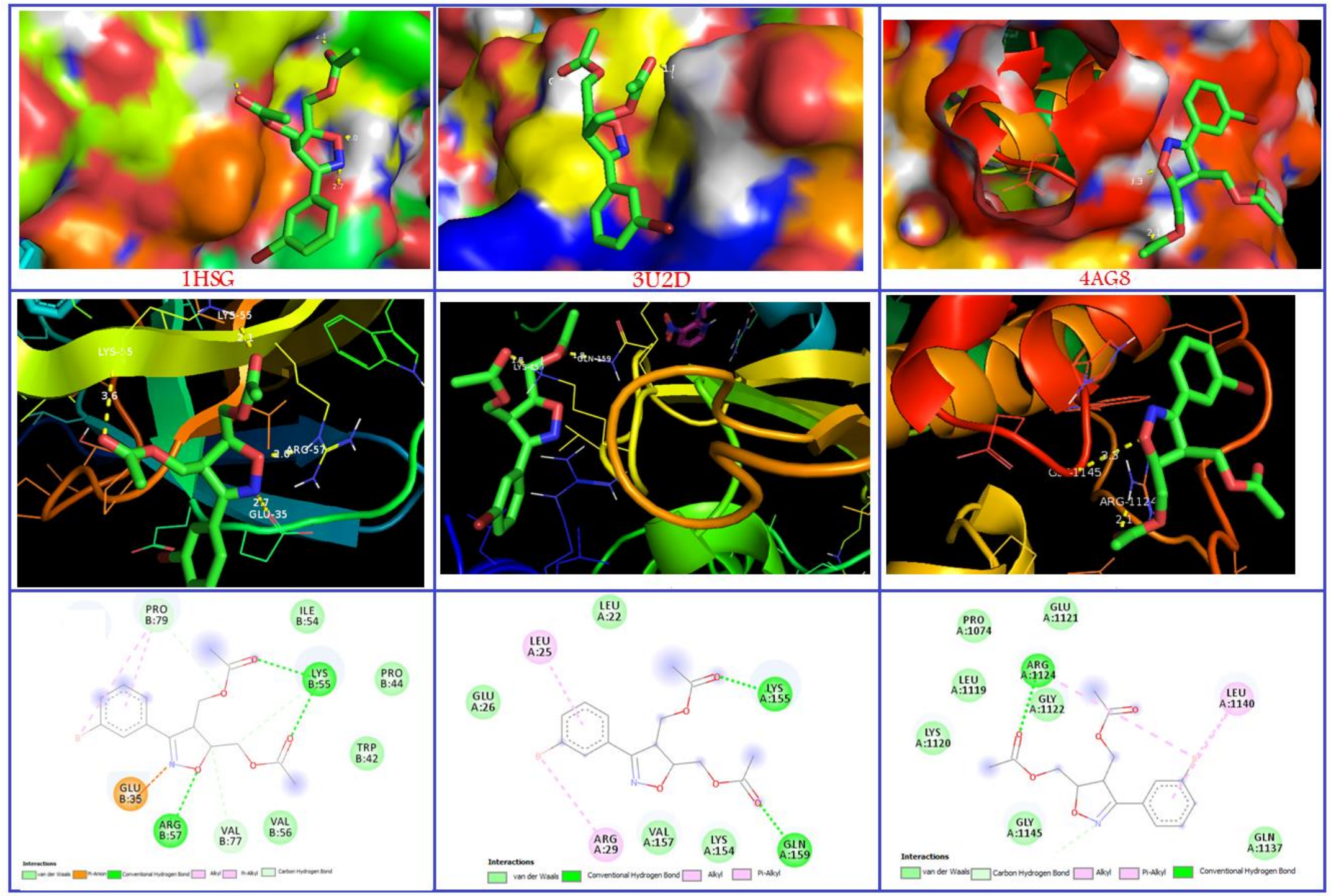

Fig. 3. 3D and 2D docking pose diagrams showing interactions of BDBD with its target proteins 1HSG, 3U2D, and 4AG8. 
Table 1. The obtained docking parameters of BDBD molecule.

\begin{tabular}{llccccc}
\hline $\begin{array}{c}\text { Protein } \\
\text { [PDB ID] }\end{array}$ & $\begin{array}{c}\text { Bonded } \\
\text { residues }\end{array}$ & $\begin{array}{c}\text { Bond distances } \\
(\AA)\end{array}$ & $\begin{array}{c}\text { Inhibition } \\
\text { constant } \\
(\mu \mathbf{M})\end{array}$ & $\begin{array}{c}\text { Intermolecular } \\
\text { energy } \\
(\mathbf{k c a l} / \mathbf{m o l})\end{array}$ & $\begin{array}{c}\text { Binding } \\
\text { energy } \\
(\mathbf{k c a l} / \mathbf{m o l})\end{array}$ & $\begin{array}{c}\text { RMSD } \\
(\AA)\end{array}$ \\
\hline 1HSG & LYS-55 & 2.1 & 33.36 & -8.20 & -6.11 & 10.21 \\
& LYS-55 & 3.6 & & & & \\
& GLU-35 & 2.7 & & & & \\
\multirow{2}{*}{ 3U2D } & ARG-57 & 2.0 & & & & \\
& LYS-155 & 1.8 & 468.17 & -6.63 & -4.54 & 11.38 \\
& GLN-159 & 1.8 & & & & \\
& ARG-1124 & 2.1 & 301.85 & -6.89 & -4.80 & 21.27 \\
\hline
\end{tabular}

\section{Conclusion}

Intermolecular interactions for BDBD molecule of reduced density gradient (RDG) as strong hydrogen bonds are depicted with the colorful diagram using Van der Walls interactions and steric effects. The energy flow from the HOMO to LUMO has been shown by the TDOS and PDOS diagram. The antibacterial and anti-inflammatory activities of BDBD against various proteins (1HSG, 3U2D, and 4AG8) were studied using molecular docking. The results of molecular docking indicate that BDBD interacts with $1 \mathrm{HSG}$ at minimum binding energy of $-6.11 \mathrm{kcal} / \mathrm{mol}$ binds to the amino acids LYS-55, GLU-35, ARG-57 receptors by $\mathrm{C}=\mathrm{O}$ bonds, $\mathrm{N} 1$ atom, $\mathrm{O} 2$ atom, respectively.

\section{References}

[1] Kwiatkowski, S., A new, efficient approach to $\alpha, \beta$-unsaturated ketones and $\beta$ hydroxy ketones from 4,5-dihydroisoxazoles, Journal of the Chemical Society, Chemical Communications, 19, 1496-1498, (1987).

[2] Annunziata, R.R., Cinquini, M., Cozzi, F., Gilardi, A., Restelli, A., Enantiomerically pure sulphinyl-4,5-dihydroisoxazoles. Part 1. Stereocontrolled synthesis of optically active $\beta$-ketols and $\gamma$-amino alcohols, Journal of the Chemical Society, Perkin Transactions 1, 1, 2289-2292, (1985).

[3] Lee, S.Y., Lee, B.S., Lee, C.W., Oh, D.Y, Synthesis of 4-oxo-2alkenylphosphonates via nitrile oxide cycloaddition: $\gamma$-Acylation of allylic phosphonates, The Journal of Organic Chemistry, 65, 256-257, (2000).

[4] Yashiro, A., Nishida, Y., Kobayashi, K., Ohno, M., $\beta$-Hydroxy Nitrile and $\beta$ Hydroxy Oxime Derivatives of [60] Fullerene by Nucleophilic Ring Cleavage of Fulleroisoxazoline and -Isoxazolidine in the Presence of Methanol, Synlett, 3, 361-362, (2000).

[5] Cwik, A., Hell, Z., Fuchs, A., Halmai, D., Solid Base Catalyzed Synthesis of 5Substituted 4,5-Dihydroisoxazoles, Tetrahedron Letters, 46, 6563-6566, (2005).

[6] Karthikeyan, K, Veenus, S.T, Lalitha, K.G., Perumal, P.T., Synthesis and antinociceptive activity of pyrazolyl isoxazolines and pyrazolyl isoxazoles, Bioorganic\&Medicanal Chemistry Letters, 19:3370-3373, (2009).

[7] Rajanarendar, E., Rama, K.S., Nagaraju, D., Govardhan R.K., Kishore B., Reddy Y.N., Environmentally benign synthesis, molecular properties prediction and anti-inflammatory activity of novel isoxazolo[5,4-d] isoxazol-3-yl-aryl- 
methanones via vinylogous Henry nitroaldol adducts as synthons, Bioorganic\&Medicanal Chemistry Letters, 25, 1630-1634, (2015).

[8] Basha, S.S., Divya, K., Padmaja, A., Padmavathi, V., Synthesis and antimicrobial activity of thiazolyl pyrazoles and isoxazoles. Research on Chemical Intermediates, 41, 10067-10083, (2015).

[9] Neetu, A., Pradeep, M., The synthetic and therapeutic expedition of isoxazole and its analogs, Medicinal Chemistry Research, 27, 1309-1344, (2018).

[10] Amir, M., Javed, S.A., Kumar H., Design and synthesis of 3-[3- (substituted phenyl)-4-piperidin-1-ylmethyl/-4-morpholin-4- ylmethyl-4,5-dihydro-isoxazol5-yl]-1H-indoles as potent antiinflammatory agents, Medicinal Chemistry Research, 19, 299-310, (2010).

[11] Gautam, K.C., Singh, D.P., Synthesis and antimicrobial activity of some isoxazole derivatives of thiophene, Chemical Science Transactions, 2, 992996, (2013).

[12] Martins, M.A.P., Pereira, C.M.P., Zimmermann, N.E.K., Cunico, W., Mouro, S., Beck, P., Zanatta, N., Bonacorso, H.G., Regiospecific synthesis of polyfluorinated heterocycles, Journal of Fluorine Chemistry, 123, 261-265, (2003).

[13] Kara, Y.S., Substituent effect study on experimental ${ }^{13} \mathrm{C}$ NMR chemical shifts of (3-(substituted phenyl)-cis-4,5-dihydroisoxazole-4,5-diyl)bis(methylene) diacetate derivatives, Spectrochimica Acta Part A: Molecular and Biomolecular Spectroscopy, 151, 723-730, (2015).

[14] Kara, Y.S., Kara, Y.S., Esme, A., Sagdinc, S.G., Crystal structure, spectral and DFT studies of [3-(3-bromophenyl)-cis-4,5-dihydroisoxazole-4,5-diyl] bis(methylene) diacetate, Journal of Applied Spectroscopy, 88, 3, 501-1-50112, (2021).

[15] Frisch, M.J., M.J., Trucks, G.W., Schlegal, H.B., Scuseria, G.E., Robb, M.A., Cheesman, J.R., Zakrzewski, V.G., Mortgomerg Jr. J.A., Stratmann, R.E., Burant, J.C., Dapprich, S., Millam, J.M., Daniels, A.D., Kudin, K.N., Strain, M.C., Farkas, O., Tomasi, J., Barone, V., Cossi, M., Cammi, R., Mennucci, J., Petersson, G.A., Ayala, P.Y., Cui, Q., Morokuma, K., Rega, N., Salvador, P., Dannenberg, J.J., Malich, D.K., Rabuck, A.D., Raghavachari, K., Foresman, J.B., Cioslowski, J., Ortiz, J.V., Baboul, A.G., Stetanov, B.B., Liu, G., Liashenko, A., Piskorz, P., Komaromi, J., Gomperts, R., Martin, R.L., Fox, D.J., Keith, T., Al Laham, M.A., Peng, C.Y., Nanayakkara, A., Challacombe, M., Gill, P.M.W., Johnson, B., Chenp, W., Wong, M.W., Andres, J.L., Gonzalez, C., Head-Gordon, M., Replogle E.S. and J.A. Pople, Gaussian 09, Revision A.1, Gaussian Inc., Wallingford CT, (2009).

[16] Keith,T., Keith T. and Millam J., GaussView, Version 5.0.9, Semichem. Inc., Shawnee Mission KS, (2009).

[17] Bekce, A.D., Density-functional thermochemistry. III. The role of exact Exchange, The Journal of Chemical Physics, 98, 5648-5652, (1993).

[18] Lee, C., Yang, W., Parr, R.G., Development of the Colle-Salvetti correlationenergy formula into a functional of the electron density, Physical Review B, 37, 7, 85-789, (1988).

[19] Lu, T., Chen, F., Multiwfn: A multifunctional wavefunction analyzer, Journal of Computational Chemistry, 33, 580-592, (2012).

[20] Humphrey, W., Dalke, A., Schulten, K., VMD: Visual molecular Dynamics, Journal of Molecular Graphics, 14, 33-38, (1996). 
[21] Johnson, E.R., Keinan, S., Morisanchez, P., Contrerasgarcia, J., Cohen, A.J., Yang, W., Revealing Noncovalent Interactions, Journal of the American Chemical Society, 132, 6498-6506, (2010).

[22] Lagunin, A., Stepanchikova, A., Filimonov, D., Poroikov, V., PASS: prediction of activity spectra for biologically active substances, Bioinformatics, 16, 747748, (2000).

[23] Panda, S.S., Chowdary, P.V.R., Jayashree, B.S., Synthesis, Antiinflammatory and Antibacterial Activity of Novel Indolyl-isoxazoles, Indian Journal of Pharmaceutical Science, 71, 684-687, (2009).

[24] Sanner, M. F., Python: A programming language for software integration and development, Journal of Molecular Grafhics and Modelling, 17, 57-61, (1999).

[25] Huey, R., Morris, G.M., Olson, A.J., Goodsell, D.S., Software News and Update A Semiempirical Free Energy Force Field with Charge-Based Desolvation, Journal of Computational Chemistry, 28, 1145-1152, (2007).

[26] Morris, G.M., Goodsell, D.S., Halliday, R.S., Huey, R., Hart, W.E., Belew, R.K., Olson, A.J., Automated Docking Using a Lamarckian Genetic Algorithm and and Empirical Binding Free Energy Function, Journal of Computational Chemistry, 19, 1639-1661, (1998).

[27] Kamalneet, K., Vinod, K., Anil, K.S., Girish K.G., Isoxazoline containing natural products as anticancer agents: A review, European Journal of Medicinal Chemistry, 77, 121-133, (2014).

[28] Maryam, A. J., Oluwakemi E., Nkululeko D., Michael S., Virtual screening, molecular docking studies and DFT calculations of FDA approved compounds similar to the non-nucleoside reverse transcriptase inhibitor (NNRTI) efavirenz, Heliyon, 6, e04642, (2020). 